Bangladesh J. Plant Taxon. 21(1): 77-81, 2014 (June)

(C) 2014 Bangladesh Association of Plant Taxonomists

\title{
HABENARIA NICOBARICA (ORCHIDACEAE), A NEW SPECIES FROM ANDAMAN AND NICOBAR ISLANDS, INDIA
}

\author{
C. Murugan ${ }^{1}$, Joju P. Alappatt ${ }^{2}$, S. Prabhu ${ }^{3}$ and W. Arisdason ${ }^{4}$ \\ Botanical Survey of India (BSI), Andaman and Nicobar Regional Centre, \\ Port Blair 744 102, Andaman and Nicobar Islands, India
}

Keywords: Habenaria nicobarica; India; Andaman and Nicobar Islands; Orchidaceae.

\begin{abstract}
A new species of terrestrial orchid Habenaria nicobarica Murugan, Alappatt, Prabhu \& Arisdason sp. nov. is described from South Nicobar Islands. Key to species of Habenaria in Andaman and Nicobar Islands, illustration and photograph of the new species are also provided.
\end{abstract}

\section{Introduction}

Orchidaceae include c. 788 genera (Mabberley, 2008) and c. 25,971 species (Joppa et al., 2011) and distributed widely in the world. In India, orchids are represented by 184 genera and 1129 species (Jalal et al., 2008), of which 150 species belonging to 59 genera are found in Andaman and Nicobar Islands.

The Andaman and Nicobar Islands in India is a repository of diverse species, including 25 endemic orchid species (Misra et al., 2012). The genus Habenaria Willd. is estimated to have approximately 750 species and distributed in every continent of the world (Comber, 1990). Among these, 100 species are recorded from India (Santapau and Henry, 1973) and only 1 species, namely $H$. andamanica Hook. f., is reported from Andaman and Nicobar Islands (Choudhury et al., 2011).

During the course of botanical explorations in Great Nicobar Biosphere Reserve and Little Nicobar Tribal Reserve, Andaman and Nicobar Islands, from 2008 to 2011, the authors have collected few interesting specimens of Habenaria. On critical study of the specimens and perusal of literature (Hooker, 1890; Jayaweera, 1981; Comber, 1990; Chowdhery, 1998; Mathew, 1998; Sinha, 1999; Pandey and Diwakar, 2008), the authors found it as an undescribed species, which is very closely allied to Habenaria koodersii J. J. Sm., but differs in leaf, flower and lip characters (Table 1). Hence, it is described here as a new species, viz., Habenaria nicobarica along with key to species, illustration and photograph, for further collection and identification in the field.

Habenaria nicobarica Murugan, Alappatt, Prabhu \& Arisdason, sp. nov.

(Figs 1, 2 b-e).

Type: INDIA, Andaman and Nicobar Islands: South Nicobar, Little Nicobar Tribal Reserve, Pulopaha (E), 25.11.2008, C. Murugan 26630 (Holotype: CAL; Isotype: PBL).

Diagnosis: Habenaria nicobarica is closely related to H. koodersii J. J. Sm. but differs in bract size, flower colour and lip characters.

\footnotetext{
${ }^{1}$ Corresponding author. E-mail: sivanthimurugan@rediffmail.com

${ }^{2}$ Forest Training Institute, Wimberligunj, Port Blair-744 206, South Andaman, Andaman and Nicobar Islands, India

${ }^{3}$ Botanical Survey of India (BSI), Andaman and Nicobar Regional Centre, Port Blair-744 102, Andaman and Nicobar Islands, India

${ }^{4}$ Botanical Survey of India, CGO Complex, Salt Lake City, Kolkata-711 064, West Bengal, India
} 
Tuberous, terrestrial herbs, up to $1 \mathrm{~m}$ high. Stems terete. Leaves spiral, 5-8, confined to the middle of stem, oblong-lanceolate, 7-12 × 2-3 cm, rounded with auricled at base, entire at margin, acuminate at apex, 3-veined. Racemes terminal, $10-20 \mathrm{~cm}$ long, lax; peduncles terete, $10-25 \mathrm{~cm}$ long. Flowers lax, light brown; bracts linear, acuminate at apex, 1.5-2.0 $\times 0.2-0.3 \mathrm{~cm}$. Dorsal sepal 10-17 mm long with $7 \mathrm{~mm}$ long filiform extension, 3-nerved; lateral sepals spreading, c. $10 \times 4 \mathrm{~mm}$ with $9 \mathrm{~mm}$ long tail, 3-nerved. Petals 2, bilobed; posterior lobe shorter than sepals, erect, linear, c. $10.0 \times 0.1 \mathrm{~mm}$; anterior lobe short, acuminate at apex. Lip 3-lobed to the base, mid lobe c. $12 \times$ $2 \mathrm{~mm}$, flat; lateral lobe linear, c. $10 \times 1 \mathrm{~mm}$; spur cylindric, narrowed towards apex, up to $27 \mathrm{~mm}$ long. Gynostemium c. $4 \mathrm{~mm}$ long. Anther canal c. $2 \mathrm{~mm}$ long; lateral rostellar arms as long as anther canals, projecting forward; central lobe indistinct; auricle 2, prominent. Stigma processes large, c. $2.0 \times 1.5 \mathrm{~mm}$, rounded at apex. Ovary obconic, c. $2.3 \times 0.2 \mathrm{~cm}$, trigonous. Capsules oblong, c. $2.0 \times 0.5 \mathrm{~cm}$.

Flowering and fruiting: October - April.

Distribution: India (Nicobar Islands).

Paratypes: INDIA, Andaman and Nicobar Islands: S. Nicobar, Little Nicobar Tribal Reserve, Pulo ulon (N), 26.11.2008, C. Murugan 26680 (PBL); Pulo Panja (N), 31.10.2009, C. Murugan 27828 (PBL). Pulopaha, 8.4.2011, C. Murugan 28322 (PBL); Great Nicobar Biosphere Reserve, $10 \mathrm{~km}$ on East-west Road, 31.10.2011, Joju P. Alappatt 337 (PBL).

Etymology: The species is named after the Nicobar Islands, the type locality and one of the plant diversity hotspots in India.

Table 1. Comparison of exomorphic characters among Habenaria koodersii, $H$. nicobarica sp. nov. and H. andamanica.

\begin{tabular}{llll}
\hline Characters & Habenaria koodersii & H. nicobarica sp. nov. & H. andamanica \\
\hline Plant height & $40-60 \mathrm{~cm}$ & $60-100 \mathrm{~cm}$ & $70-80 \mathrm{~cm}$ \\
Number of leaves & $7-9$ & $5-8$ & 7 \\
Leaf size & $13.5-17.0 \mathrm{~cm}$ long & $7-12 \mathrm{~cm}$ long & $5-15 \mathrm{~cm}$ long \\
Inflorescence & $21-31 \mathrm{~cm}$ long & $10-20 \mathrm{~cm}$ long & $25-40 \mathrm{~cm}$ long \\
Peduncle & $12-19 \mathrm{~cm}$ long & $10-25 \mathrm{~cm}$ long & $5-7 \mathrm{~cm} \mathrm{long}$ \\
Bract & c. $2.8 \mathrm{~cm}$ long & $1.5-2.0 \mathrm{~cm}$ long & $2-3 \mathrm{~cm}$ long \\
Flower colour & Greenish white & Light brown & White with brown \\
Dorsal sepal & $1.1 \mathrm{~cm}$ with c. $4 \mathrm{~mm}$ & $1.0-1.7 \mathrm{~cm}$ with c. $7 \mathrm{~mm}$ & $1.2 \mathrm{~cm}$ without thread \\
& long thread & long thread & \\
Petals & $1.0-1.1 \mathrm{~cm}$ long, & $1 \mathrm{~cm}$ long, lobed at base & $1.0-1.4 \mathrm{~cm}$ long, unlobed \\
& unlobed at base. & Mid lobe (c. $1.2 \mathrm{~cm}$ long) & $\begin{array}{l}\text { Mid lobe linear, 3-fid } \\
\text { (c. } 1.5 \mathrm{~cm} \text { long) longer than }\end{array}$ \\
Lip & $\begin{array}{l}\text { Mid lobe shorter than } \\
\text { side lobe }\end{array}$ & longer than side lobe & side lobe \\
& & Tubular, c. $2.7 \mathrm{~cm}$ long & clavate \\
Spur & Tubular, narrow & narrow towards apex & \\
& towards apex & &
\end{tabular}

Key to species of Habenaria Willd. in Andaman and Nicobar Islands.

1 Flowers white; sepals without filiform attachment near apex; lip laciniate.

H. andamanica

- Flowers light brown; sepals with filiform attachment near apex; lip 3-fid.

H. nicobarica sp. nov. 


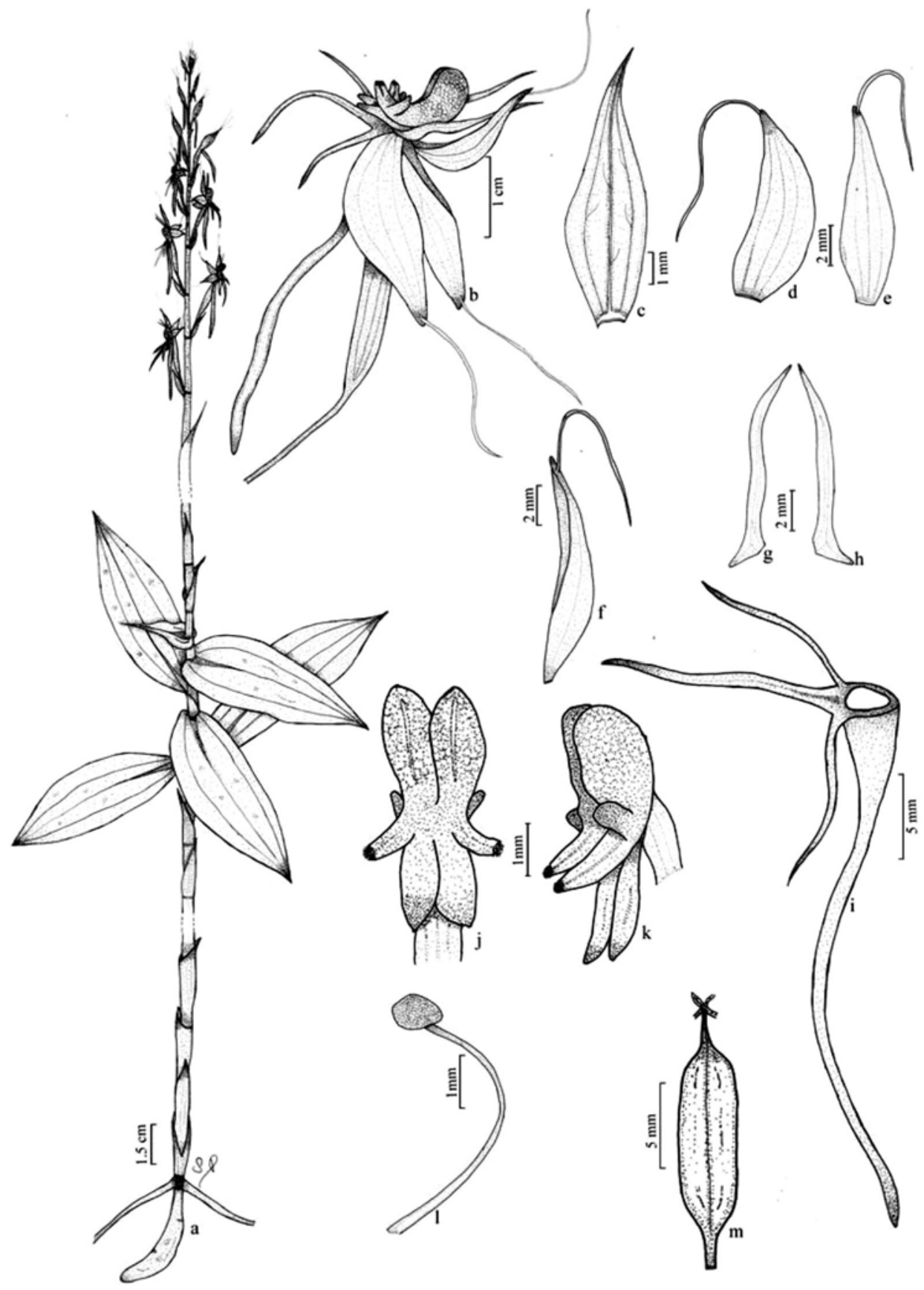

Fig. 1. Habenaria nicobarica sp. nov. (Orchidaceae). a. habit; b. flower; c. bract; d-f. sepals; g-h. petals; i. lip; j-k. column; l. pollinaria; m. capsule. 

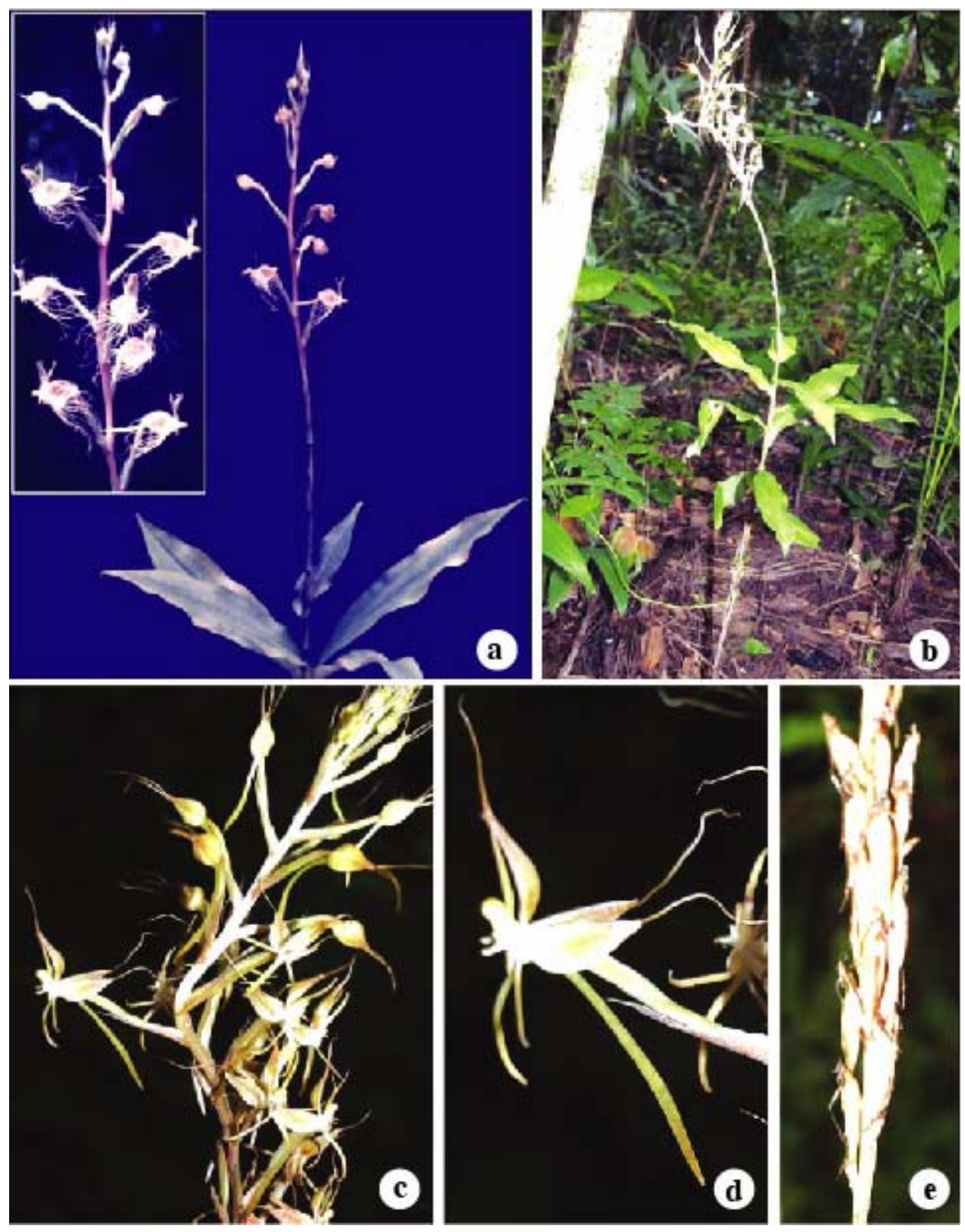

Fig. 2a. Habenaria andamanica Hook. f. (Habit with inflorescence); b-e. Habenaria nicobarica sp. nov. b. habit; c. inflorescence; d. flower; e. capsule.

\section{Acknowledgements}

The authors are thankful to Dr. M. Sanjappa, former Director and Dr. P. Singh, Director, Botanical Survey of India, Kolkata, for providing facilities and constant support. They are also grateful to Shri H.J. Chowdhery, former Secretary \& PCCF, Shri D.V. Negi, former PCCF (WL), Dr. Shashi Kumar, Secretary \& PCCF, the former Divisional Forest Officers, Dr. P. Viswakannan, 
and Dr. S. Dinesh Kannan, Department of Environment and Forests, Andaman and Nicobar Islands for their permission and encouragement during the field studies and Dr. Huber Kurzweil, Singapore Herbarium, Singapore, for confirmation of novelty.

\section{References}

Choudhury, S., Mukheerjee, S.K. and Chowdhery, H.J. 2011. Distribution and diversity of the genus Habenaria Willdenow in India. In: Ghosh, C. and Das, A.P. (Eds), Recent Studies in Biodiversity and Traditional Knowledge in India. Sarat Book House, Kolkata, pp. 81-90.

Chowdhery, H.J. 1998. Orchid Flora of Arunachal Pradesh. Bishen Singh Mahendra Pal Singh, Dehra Dun, India, pp. 440-452.

Comber, J.B. 1990. Orchids of Java. Royal Botanic Gardens, Kew, pp. 60-66.

Hooker, J.D. 1890. Orchidaceae. In: Hooker, J.D. (Ed.), The Flora of British India, Vol. 6. L. Reeve \& Co. Ltd., London, pp. 1-198.

Jalal, J.S., Kumar, P., Rawat, G.S. and Pangtey, Y.P.S. 2008. List of species. Orchidaceae, Uttarakhand, Western Himalaya, India. Check List 4: 304-320.

Jayaweera, D.M.A. 1981. Orchidaceae. In: Dassanayake, M.D. (Ed.), Revised Handbook to the Flora of Ceylon, Vol. 2. Oxford \& IBH Publishing Co. Ltd., New Delhi, pp. 4-388.

Joppa, L.N., Roberts, D.L. and Pimm, S.L. 2011. How many species of flowering plants are there? Proc. R. Soc. B 278: 554-559.

Mabberley, D.J. 2008. Mabberley’s Plant Book - A portable dictionary of Plants, their Classification and Uses ( $3^{\text {rd }}$ Edition.). Cambridge University Press, Cambridge.

Mathew, S.P. 1998. A supplementary report on the flora and vegetation of the Bay Islands, India. J. Econ. Taxon. Bot. 22: 249-272.

Misra, S., Nayakm P.H. and Panda, S.P. 2012. Aerides rosea Lodd. ex Lindl. \& Paxton (Orchidaceae) - A new record from the Andaman and Nicobar Islands, India. J. Bombay Nat. Hist. Soc. 109: 226-229.

Pandey, R.P. and Diwakar, P.G. 2008. An integrated checklist of Andaman and Nicobar Islands, India. J. Econ. Taxon. Bot. 32: 403-500.

Santapau, H. and Henry, A.N. 1973. A Dictionary of the Flowering Plants in India. Council of Scientific \& Industrial Research, New Delhi.

Sinha, B.K. 1999. Orchidaceae. In: Hajra, P.K. and Rao, P.S.N. (Eds), Flora of Great Nicobar Islands. Botanical Survey of India, Calcutta, pp. 420-447. 